\title{
SIMULASI SISTEM KONTROL KLORINASI PADA PEMBANGKIT LISTRIK TENAGA UAP SEBALANG UNIT 5 \& 6 LAMPUNG SELATAN Adi Hutama Ginting ${ }^{1}$, Emir Nasrullah ${ }^{2}$, Noer Soedjarwanto ${ }^{3}$
}

\author{
Jurusan Teknik Elektro Universitas Lampung, Bandar Lampung \\ Jl. Prof. Sumantri Brojonegoro No.1 Bandar Lampung 35145 \\ 1 adiginting@ymail.com, ${ }^{2}$ emas@unila.ac.id, ${ }^{3}$, noersoedjarwanto@gmail.com
}

\begin{abstract}
ABSTRAK
Pembangkit Listrik Tenaga Uap. Di dalam proses produksinya, terdapat sistem pendingin yang digunakan untuk efisiensi kerja, yaitu sirkulasi (daur ulang uap), dan pendingin pada motor dan pompa dengan menggunakan suhu alam air laut Pada kenyataannya, air laut alam ini banyak mengandung biota-biota laut, termasuk ikan, udang, dan lumut, yang dalam jangka panjang dapat membahayakan proses pendinginan, karena di dalam radiator (tabung-tabung pendingin) akan tumbuh lumut, dan juga ikan, yang dapat menyumbat sirkulasi air laut ini, sehingga diperlukan suatu sistem yang dapat menghindarkan biota-biota laut ini masuk ke dalam sistem sirkulasi air pendingin ini, yaitu dengan memberikan cairan klorin kadar tinggi pada jalur (intake) masukan air laut, yang dapat mengusir biota, dan mematikan lumut. oleh sebab itu diperlukan pembuatan Simulasi Sistem Klorinasi pada Pembangkit Listrik Tenaga Uap (PLTU), tujuannya untuk menjaga efisiensi kerja sistem agar bekerja lebih baik.
\end{abstract}

\section{ABTRACT}

Steam Power Plant. Inside its production proccess, there is a cooling system which is used for working efficiency, it is the circulation (recycling steam), cooler on the motor and the pump by using the natural temperature of the sea water. Actually, this natural sea water contains a lot of marine creatures, including fish, shrimp, and moss, which in a long term, can endanger cooling process.because within the radiator (cooling tubes), moss can grow and fish also can clog the circulation of ocean water, so a system is needed, that can prevent the marine creatures from entering the cooling water circulation system is needed, it is by giving a high concentration of chlorine liquid at seawater entering intake, which can dislodge sea creatures, and kill moss. therefore the making chlorination simulation system on Steam power plant is needed. The purpose is to keep the working efficiency of system in order to work better.

\section{PENDAHULUAN}

Pembangkit listrik ada bermacam-macam, salah satunya yang sekarang sedang giatgiatnya dibangun adalah Pembangkit Listrik Tenaga Uap, yang bekerja dengan memanfaatkan energi tekanan uap dari proses perebusan air demineral air laut oleh batu bara untuk menggerakkan turbin, dan generator, yang akhirnya menghasilkan listrik Di dalam proses produksinya, terdapat sistem pendingin yang digunakan untuk efisiensi kerja, yaitu sirkulasi (daur ulang uap), dan pendingin pada motor dan pompa dengan menggunakan suhu alam air laut. Pada kenyataannya, air laut alam ini banyak mengandung biota-biota laut, termasuk ikan, udang, dan lumut, yang dalam jangka panjang dapat membahayakan proses pendinginan, karena di dalam radiator (tabung-tabung pendingin) akan tumbuh lumut, dan juga ikan, yang dapat menyumbat sirkulasi air laut ini, sehingga diperlukan suatu sistem yang dapat menghindarkan biota-biota laut ini masuk ke dalam sistem 
sirkulasi air pendingin ini, yaitu dengan memberikan cairan klorin kadar tinggi pada jalur (intake) masukan air laut, yang dapat mengusir biota, dan mematikan lumut.

\section{TINJAUAN PUSTAKA}

\subsection{Logika}

Logika adalah sesuatu yang dapat diterima oleh akal, dalam hal ini berhubungan dengan keteknikan. Logika diimplementasikan dalam bentuk simbol, yang dikenal dengan logic gate (gerbang logika). Simbol tersebut tidak menyatakan alat, hanya menyatakan fungsinya saja. Adapun jenis gerbang logika dasar, yaitu.

A. Gerbang Not

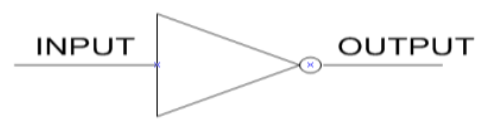

B. Gerbang Or

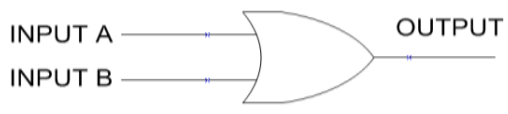

C. Gerbang And

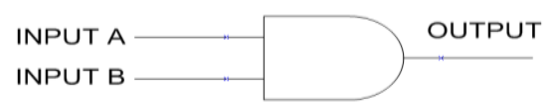

Gambar 1. Gerbang Logika

\subsection{Switch}

Switch adalah komponen elektrikal yang berfungsi untuk memberi sinyal atau untuk memutus atau menyambung suatu sistem kontrol. Switch berupa komponen kontaktor mekanik yang digerakkan karena suatu kondisi tertentu, seperti contoh: pressure switch, kontaktornya akan bergerak karena adanya tekanan mekanik yang melebihi tekanan normalnya. Switch terdiri dari satu set atau lebih kontaktor yang terdiri dari Common Normally Open (NO) dan Normally Close (NC). Berikut adalah gambar komponen limit switch. Limit Switch adalah salah satu contoh switch yang digunakan untuk memutus atau memberi isyarat suatu sistem kontrol karena lengan switch tersentuh suatu objek. Biasanya digunakan untuk pengontrol titik maksimum dan minimum dari pergerakan benda, contohnya lengan Disconnecting Switch, Belt Conveyor, dan lain-lain.

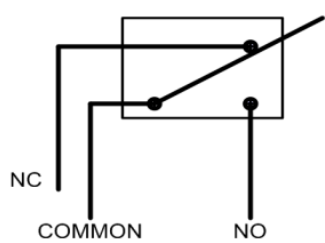

Gambar 2. Komponen Limit Switch

\subsection{Kontaktor}

Kontaktor adalah komponen elektrikal yang berfungsi untuk memutus atau menyambung arus daya (arus beban). Sistem kerja kontaktor sama seperti relay, yang membedakan adalah kemampuan batang kontaktor lebih besar dalam mengalirkan arus daripada relay. Di dalam kontaktor terdapat komponen elektromagnetik (coil magnetic) dan lengan-lengan kontaktor.
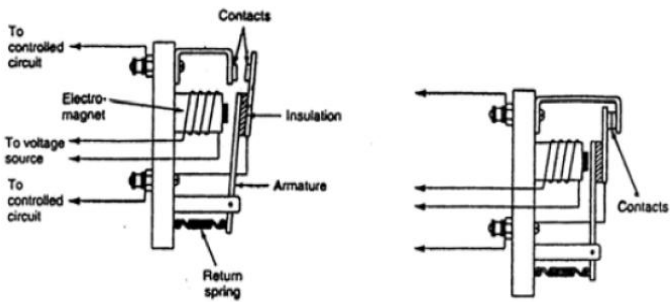

Gambar 3. Komponen Kontaktor

\subsection{Kontrol Motor 3 Phase}

Motor 3 phase adalah salah satu jenis motor listrik yang bekerja menggunakan sumber tegangan 3 phase yaitu $\mathrm{R}, \mathrm{S}, \mathrm{T}$, dan $\mathrm{N}$. Adapun nilai tegangan antara phase $\mathrm{R}, \mathrm{S}$, dan $\mathrm{T}$ adalah 380 Volt, sedangkan nilai tegangan antara phase dengan Netral adalah 220 Volt. Motor 3 phase dapat bekerja dalam 2 arah, yaitu forward dan reverse. Cara mengontrol arah putaran motor ini yaitu dengan mengatur hubungan coil motor dengan sumber listrik. Untuk arah putar forward, menggunakan konfigurasi $\mathrm{R}, \mathrm{S}, \mathrm{T}$ dengan $\mathrm{U}$, $\mathrm{V}, \mathrm{W}$. Sedangkan untuk arah putaran reverse, konfigurasinya adalah : $\mathrm{R}, \mathrm{S}, \mathrm{T}$ dengan $\mathrm{U}, \mathrm{W}$, V; atau R, S, T dengan W, V, U 


\subsection{Solenoid Valve}

Solenoid Valve adalah komponen elektrikal yang berfungsi untuk menggerakkan valve udara bertekanan untuk menggerakkan valve mekanik. Solenoid valve menggunakan tegangan kerja DC, yaitu : 12 Volt, 24 Volt, 48 Volt dan 110 VDC.

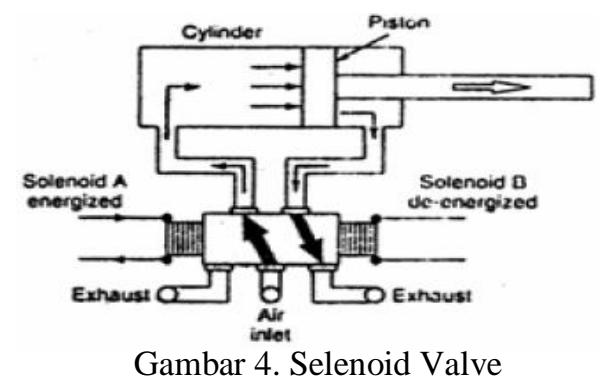

\subsection{Electrochlorination}

Electrochlorination adalah suatu alat elektrik yang berfungsi untuk mengubah atau memecah senyawa air laut yang terdiri dari $\mathrm{NaCl}$ dan $\mathrm{H} 2 \mathrm{O}$ menjadi $\mathrm{NaOCL}$ dan $\mathrm{H} 2$. Prinsip kerjanya adalah dengan mengalirkan energi listrik kedalam tabung yang berisi anoda dan katoda yang dipisahkan oleh air laut. Berikut adalah skematik proses electrochlorination

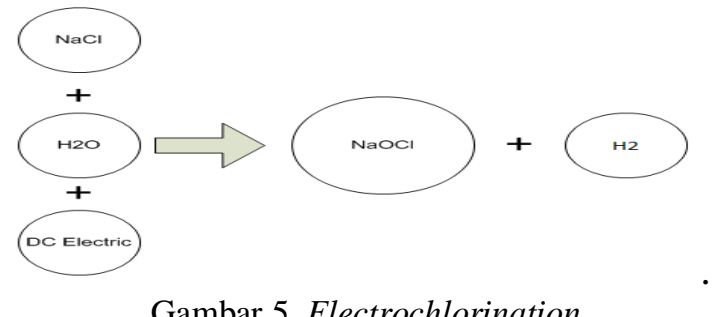

Gambar 5. Electrochlorination

\subsection{Sensor Switch}

Sensor switch adalah komponen elektrikal yang berfungsi untuk memberikan kondisi on atau off, jika suatu materi yang diukur telah mencapai kondisi tertentu. Prinsip kerjanya sama dengan thermo switch pada setrika listrik, yang akan memutuskan arus listrik jika temperatur yang diinginkan telah tercapai

\subsection{Sistem Program}

\section{PLC (Programmable Logic Control)}

Otomatisasi merupakan salah satu realisasi dari perkembangan teknologi, dan merupakan satu-satunya alternatif yang tidak dapat dielakkan lagi untuk memperoleh sistem kerja yang sederhana, praktis dan efisien, sehingga memperoleh hasil dengan tingkat keakuratan yang tinggi. Dalam segi waktu juga harus dipertimbangkan, karena dengan semakin pendek waktu yang diperlukan untuk proses produksi, maka akan mendapatkan kualitas lebih jika dibandingkan dengan proses produksi yang menggunakan waktu lebih lama. Selain jumlah produksi lebih banyak, biaya pengoperasiannya juga dapat ditekan seminim mungkin serta membutuhkan tenaga yang lebih sedikit, sehingga proses produksi tersebut memperoleh keuntungan yang lebih tinggi

\section{METODE PENELITIAN 3.1 Metode Penelitian}

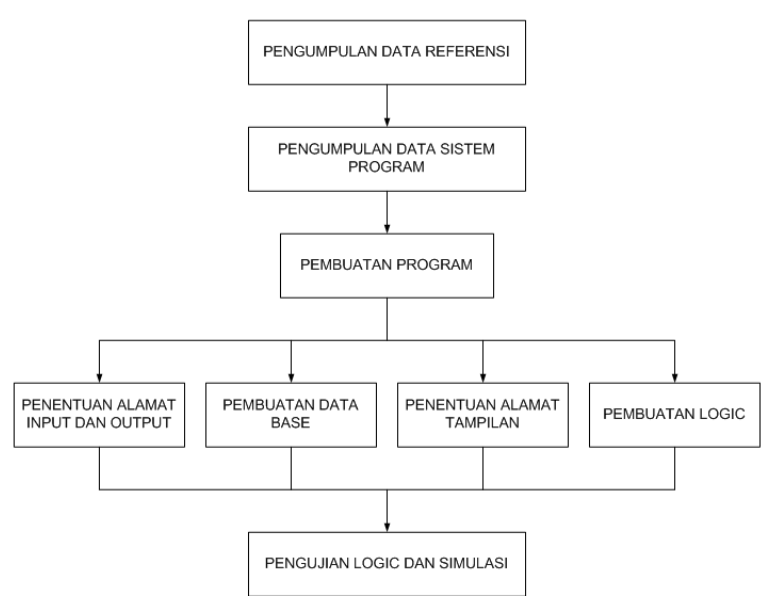

Gambar 6. Blok Metode Penelitian

1. Penentuan alamat input dan output, yaitu suatu sistem untuk menentukan alamat input dan output mana yang akan digunakan pada komputer yang berinteraksi dengan hardware (sensor sebagai alamat input, dan motor, valve sebagai alamat output).

2. Pembuatan data base, yaitu suatu cara memasukkan data-data referensi yang nantinya digunakan untuk pembanding suatu data masukan, yang akhirnya menjadi suatu perintah keluaran untuk menggerakkan valve atau motor.

3. Penentuan alamat tampilan, yaitu suatu sistem menentukan alamat yang 
akan digunakan sebagai tampilan display pada PC, sehingga dapat dioperasikan dengan mudah oleh pengguna.

4. Pembuatan logic, adalah suatu langkah utama dalam membuat program kontrol dimana pada sistem ini, dirancang semua logic diagram untuk menjalankan suatu system.

5. Pengujian logic dan simulasi, yaitu suatu tahapan, dimana logic control yang telah dibuat, dapat beroperasi dengan baik sesuai dengan sistem kerja yang diinginkan.

\subsection{Perancangan Program Kontrol}

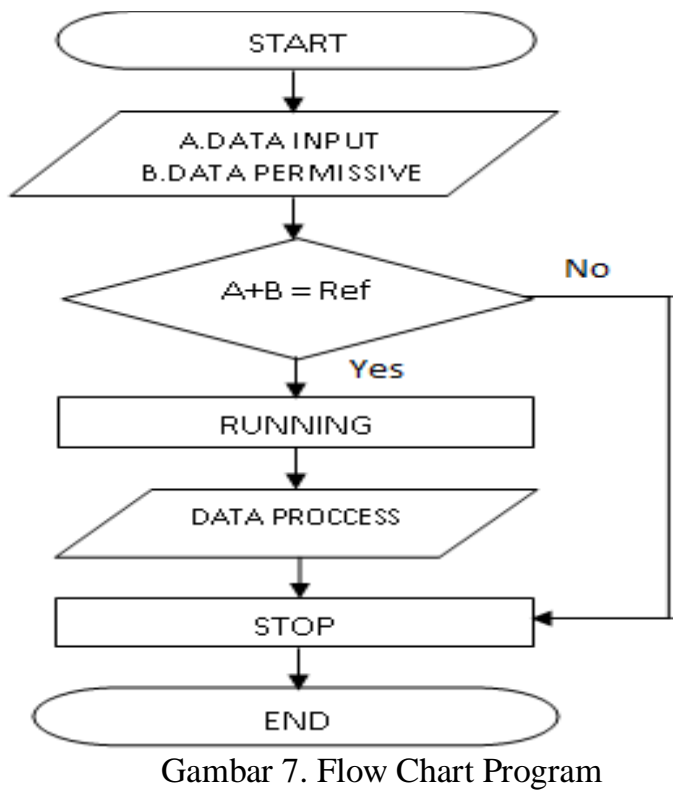

Pada gambar flow chart di atas, proses program berlangsung yaitu :

1. Start, merupakan proses awal menjalankan program untuk mengeksekusi motor pompa maupun valve pada suatu sistem,

2. Data input, merupakan suatu masukan bagi proses kontrol simulasi, yang terdiri dari masukan data switch pada valve, atau kondisi $\mathrm{MCB}$, dan juga kondisi level switch dan kadar chlorin.

3. Data permissive, merupakan suatu masukan bagi proses kontrol simulasi yang terdiri dari izin eksekusi yang merupakan data input pula yang berupa kondisi remote/lokal pengoperasian motor maupun valve.

4. Running, adalah kondisi running atau bekerjanya suatu pompa atau valve.

5. Data proses, merupakan data input yang dihasilkan dari proses running suatu sistem, seperti level tanki penuh atau belum, kondisi flow air, dsb,

6. Stop, merupakan proses akhir dari suatu kontrol simulasi ini, dimana bila kondisi data proses telah sesuai dengan settingan, maka motor, atau valve berhenti bekerja, dan jika belum terpenuhi, pompa dan valve tersebut tetap bekerja.

\section{Logic sensor}

Berikut adalah gambar diagram ladder untuk input sensor :

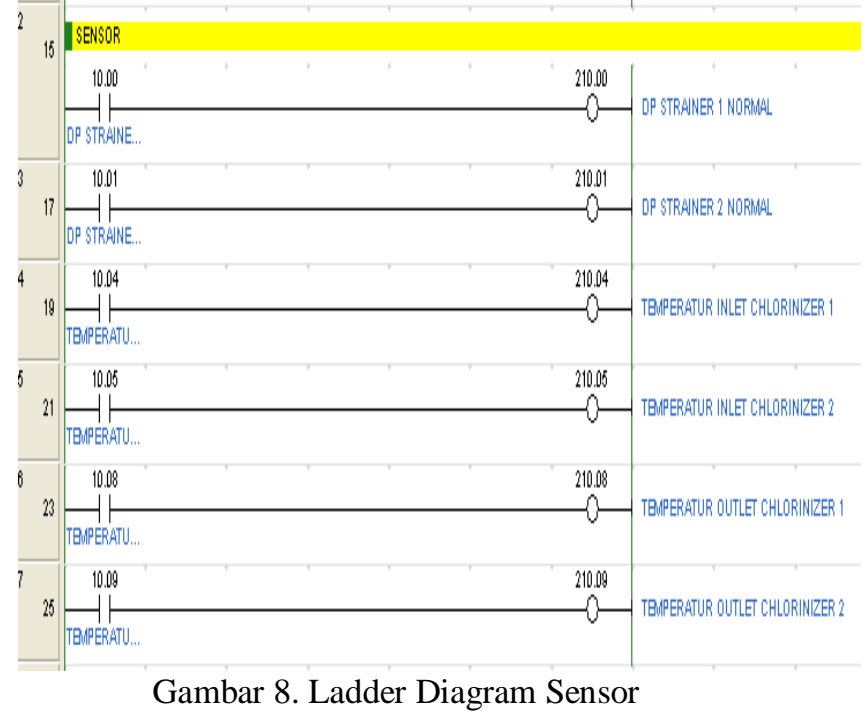

Pada gambar di atas, terlihat bahwa semua sensor merupakan kontak NO (Normally Open), kecuali sensor flow atau aliran, memiliki sifat kontak NC (Normally Close). Jumlah jalur ladder untuk sensor ini adalah 6 Rung yaitu dari Rung 2 sampai Rung 7. Semua indikator diumpankan terlebih dahulu ke dalam relay internal program PLC, supaya dapat digunakan untuk mengontrol lebih banyak. Yaitu dari 210.00 sampai 210.09, sehingga untuk kontrol yang bersangkutan dengan sensor-sensor ini menggunakan kontaktor dari relay yang berhubungan dengan sensor. 


\section{Logic booster pump 1}

Untuk ladder program control Booster Pump

1 dapat dilihat sebagai berikut :

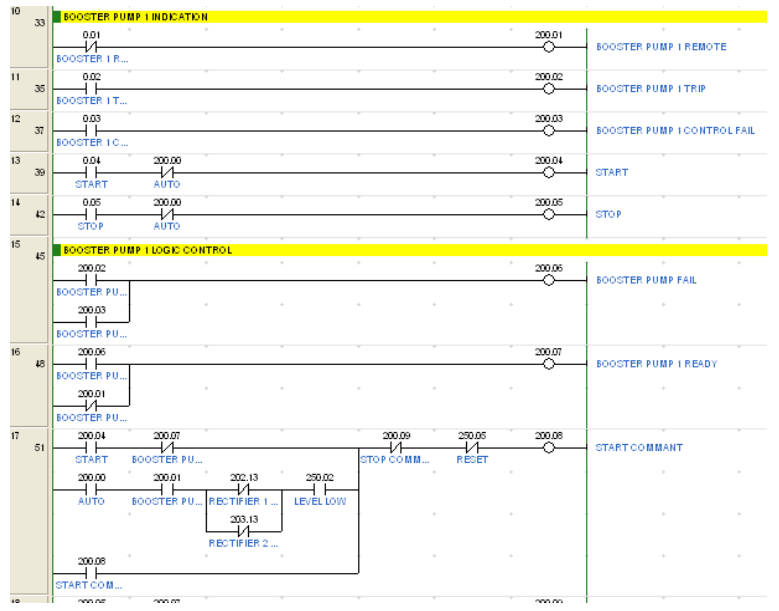

Gambar 9. Ladder Booster Pump 1

Pada gambar di atas, logic control untuk booster pump 1 dibagi menjadi 2 kelompok, yaitu logic booster pump 1 indikator, yang terdiri dari 5 Rung, dan logic control booster pump 1, yang berfungsi menjalankan booster pump 1 baik secara manual maupun auto, dan untuk men-stop booster pump tersebut.

\section{ANALISA}

Adapun analisa yang dapat diambil dari pembuatan simulasi Chlorination System Pada PLTU Sebalang 2 x 100 MW adalah :

1. Interlock relay internal pada Ladder Logic Diagram.

2. Interface Logic Ladder Diagram dengan Mimik Designer.

3. Waktu pengisian dan pengosongan tanki.

\section{A. Interlock Relay Internal Pada Ladder Logic Diagram}

Interlock relay adalah kombinasi antara coil, dengan kontaktor pada relay 1 dengan relay lainnya dan tidak menyebabkan gangguan proses kerja relay lainnya. Dalam pembuatan ladder logic ini semua jenis tombol start dan stop dibuat sebagai tombol momentary, artinya tombol ini bekerja sebagai push on saja, dan harus dikunci untuk melanjutkan proses. Berikut adalah gambar interlock relay:

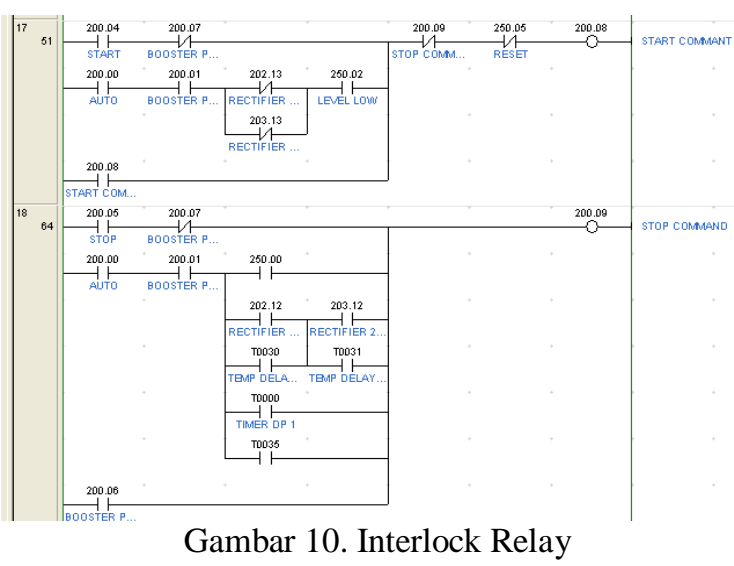

\section{B. Interface Logic Ladder dengan Mimik Designer}

Logic auto atau manual dapat dipilih dengan menekan tombol mode auto pada alamat 0.00 , yang sudah dilink dengan tampilan designer. Pada gambar di atas, terlihat bahwa auto sistem dapat terjadi jika relay 200.00 telah aktip. Dan untuk mengaktifkan relay ini, diperlukan persyaratan Booster Pump 1 atau 2 ready (alamat 200.07 atau 201.06 berwarna hijau), rectifier 1 atau 2 ready (dinyatakan dalam kontak 202.13 atau 203.13 berwarna hijau, dan Dosing 1 atau Dosing 2 ready (dinyatakan dalam kontak 204.08 atau 205.08 berwarna hijau). Hal ini bertujuan supaya dalam kondisi auto, menghindari kesalahan, yang dapat membahayakan peralatan dalam Chlorination System, seperti, Booster pump tidak running, tetapi Rectifier selalu running, dll.

Adapun tampilan Designer pada saat tombol auto ditekan adalah sebagai berikut :

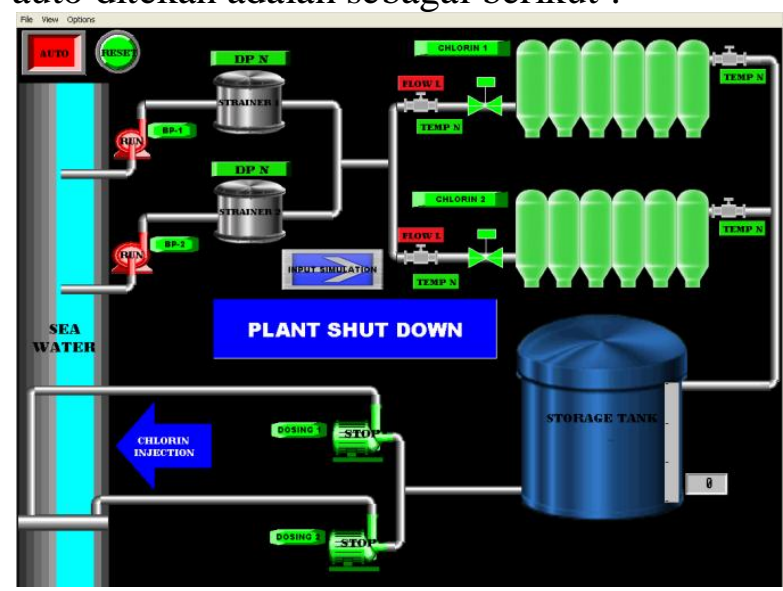

Gambar 11. Tampilan Designer 


\section{Waktu Pengisian dan Pengosongan Tanki}

Berdasarkan nilai perhitungan waktu pengisian pada Bab III, dihasilkan nilai waktu pengisian adalah 90 detik dan 45 detik. Hal ini dapat dibuktikan dengan mengaktifkan ladder logic dan tampilan designer dan diukur menggunakan stop watch. Dari hasil pengukuran dihasilkan lamanya waktu pengisian tanki ini adalah :

a) Pompa booster hanya 1 yang running, berdasarkan perhitungan adalah 90,00 detik, sedangkan dengan stop watch adalah 90,12 detik, yang berarti terdapat 0,12 detik,

b) Pompa booster 1 dan 2 running, lamanya waktu pengisian berdasarkan perhitungan adalah 45,00 detik, sedangkan dengan stop watch adalah 44,59 detik yang berarti ada selisih waktu yaitu 0,41 detik.

c) Dosing pump speed 1, waktu yang dibutuhkan untuk pengosongan tanki dari level penuh 3 meter sampai 0 meter berdasarkan perhitungan adalah 144,00 detik, dengan menggunakan stop watch adalah 143,65 detik, sehingga terdapat selisih 0,35 detik.

d) Dosing pump speed 2, waktu yang dibutuhkan untuk pengosongan tanki dari level penuh 3 meter sampai 0 meter berdasarkan perhitungan adalah 72,00 detik, dengan menggunakan stop watch adalah 72,95 detik, sehingga terdapat selisih 0,95 detik.

e) Dosing pump speed 3, waktu yang dibutuhkan untuk pengosongan tanki dari level penuh 3 meter sampai 0 meter berdasarkan perhitungan adalah 48 detik, dengan menggunakan stop watch adalah 48,50 detik, sehingga terdapat selisih 0,50 detik.

f) Dosing pump speed 4, waktu yang dibutuhkan untuk pengosongan tanki dari level penuh 3 meter sampai 0 meter berdasarkan perhitungan adalah 36 detik, dengan menggunakan stop watch adalah 36,12 detik, sehingga terdapat selisih 0,12 detik.

Hal ini disebabkan karena penekanan stop watch yang kurang tepat, dan juga terdapat jeda waktu pada program PLC antara link Designer dengan Ladder logic.

\section{KESIMPULAN DAN SARAN \\ 5.1 Kesimpulan}

Dengan terselesaikannya Tugas Akhir yang berjudul simulasi Klorinasi Sistem Pada Pembangkit Listrik Tenaga Uap 2 x 100 MW, maka penulis dapat menyimpulkan bahwa :

1. Program simulasi ini berdasarkan pada waktu yang diperlukan pompa untuk mengisi storage tanki.

2. Simulasi ini dapat diimplementasikan pada sistem klorinasi yang ada di PLTU sebalang dengan spesifikasi hardware seperti kecepatan pompa, tegangan dan lain lain disesuaikan dengan simulasi.

3. Link antara program ladder dengan tampilan, membutuhkan program tambahan, yang sudah 1 paket dengan program ladder dan tampilannya dan disebut sebagai simulator.

\subsection{Saran}

Dengan terselesaikannya Tugas Akhir yang berjudul simulasi Chlorination System Pada Pembangkit Listrik Tenaga Uap 2 x 100 MW, maka penulis dapat memberi saran sebagai berikut :

1. Sistem Khlorinasi disarankan mempunyai sistem perawatan/pembersihan otomatis seperti teknologi bioremedial. supaya dapat bekerja secara optimal

2. Disarankan PLC terintegrasi dengan Human Machine interface sehingga ketika ada upgrade sistem bisa dapat langsung dilakukan, begitu juga dengan monitoring

3. Dalam merancang suatu sistem auto, hendaknya persyaratan auto, yaitu kondisi-kondisi vital dari panel-panel motor dimasukkan dalam logic, sehingga meminimalkan terjadinya kegagalan sistem kerja auto yang dapat mengakibatkan kerusakan pada komponen komponen hardware seperti motor, valve, dll. 


\section{DAFTAR PUSTAKA}

[1] Dokumen PT. PLN (Persero), Kontrol Instrument. Pusdiklat Udiklat Suralaya 2010.

[2] Dokumen PT. PLN (Persero), Transduser and Sensor Pusdiklat Udiklat Suralaya, 2010.

[3] Dokumen PT. PLN (Persero), Hubungan PLC dan HMI. Pusdiklat Udiklat Suralaya, 2010.

[4] Horikawa, Shiokoji. SFC Intuduction Guide, Omron Industrial Automation Globa. 2010.

[5] Jepoe, Adhi. Water Desinfection Solution. OxiMax. 2010.

[6] Dokumen PT. PLN (Persero) Pusdiklat Udiklat, Instrument and Control System. Pusdiklat Udiklat Suralaya. 2010.

[7] Omron. "Manual Handbook”. Cx-One Omron Programming. 2002.

[8] Omron. "Manual Handbook". Cx- One Designer. 2002. 